\title{
GANGLION CYST OF THE KNEE: A RETROSPECTIVE REVIEW OF A CONSECUTIVE CASE SERIES
}

\author{
Ivan Bojanić, Damjan Dimnjaković and Tomislav Smoljanović \\ Department of Orthopedic Surgery, Zagreb University Hospital Centre, \\ School of Medicine, University of Zagreb, Zagreb, Croatia
}

\begin{abstract}
SUMMARY - The aim of this study was to describe relevant medical history, clinical symptoms and outcomes in 12 patients having undergone surgical treatment of intra-articular ganglion cysts of the knee at our Department from January 2010 to June 2016. Patient demographics, medical history, knee manifestations, management and outcome were evaluated. The mean patient age was 26.4 (range, 16-46) years. There were seven female and five male patients. Duration of symptoms prior to the operation varied from 2 months to 3 years (mean, 17.1 months). All patients had preoperative magnetic resonance imaging work-up of the knee. Pain was the most common clinical presentation. All patients were surgically treated arthroscopically, and an additional open approach was used in only one of the patients. There were no complications during surgery and the postoperative period was uneventful in all patients. The mean follow up period was 43.5 (range, 9-83) months and no recurrence was observed. All patients remained symptom-free with full range of motion at final follow up. Despite a wide range of intra-articular ganglion cyst presentations and symptoms, our cohort demonstrated an excellent remission rate and functional prognosis following surgical treatment of the ganglion cysts of the knee.
\end{abstract}

Key words: Ganglion cysts - diagnosis; Ganglion cysts - therapy; Knee - diagnostic imaging; Knee surgery; Arthroscopy; Croatia

\section{Introduction}

Ganglion cysts are benign, soft tissue formations arising from the joint capsule or tendon sheath and contain mucinous fluid ${ }^{1}$. They occur most frequently on the dorsum of the wrist, the palm of the hand, and the dorsolateral aspect of the foot. Ganglion cysts within the knee joint are unusual lesions and may produce clinical manifestations mimicking internal derangement of the knee.

Intra-articular ganglion cyst of the knee was first reported by Caan ${ }^{2}$ in 1924, who incidentally found a

Correspondence to: Damjan Dimnjakovic, $M D, P h D$, Department of Orthopedic Surgery, Zagreb University Hospital Centre, Šalata 6/7, HR-10000 Zagreb, Croatia

E-mail:ddimnjak@gmail.com

Received January 4, 2017, accepted April 18, 2017 ganglion cyst of the anterior cruciate ligament (ACL) at autopsy. Nowadays, with the widespread use of magnetic resonance imagining (MRI) and arthroscopy in routine orthopedic practice for knee disorders, these intra-articular lesions are being detected more often. The reported prevalence of these lesions was $0.2 \%$ $1.3 \%$ among patients referred for MRI and $0.1 \%-0.6 \%$ among those undergoing arthroscopic examination ${ }^{3-9}$. Although they can occur at any age and even in childhood, the incidence of this disorder is highest between the ages of 20 and 40 years, and is more common in men $^{3-13}$. Typical locations of these lesions within the knee joint are the ACL, followed by the posterior cruciate ligament $(\mathrm{PCL})$, then menisci, especially medial meniscus, or infra-patellar fat pad $^{3-13}$.

Intra-articular ganglion cysts of the knee do not have specific symptoms and the symptoms depend on 
their size and location within the knee joint ${ }^{7-13}$. They can be responsible for pain, swelling, effusion, extension deficit, and limitation of flexion. Although the majority of these cysts are asymptomatic and are found incidentally during the MRI work-up or diagnostic arthroscopy, the cysts found to be symptomatic usually require treatment ${ }^{7-13}$. Various treatment modalities have been reported, such as percutaneous aspiration under ultrasound guidance, percutaneous aspiration under computerized tomography (CT) guidance, arthroscopic resection, and open excision ${ }^{7-13}$.

The purpose of this retrospective study was to analyze a series of 12 cases of surgically treated intra-articular ganglion cysts of the knee in order to better understand and improve the treatment of this disorder.

\section{Materials and Methods}

A hand search of operating room logs from the Department of Orthopedic Surgery, Zagreb University Hospital Centre, Zagreb, Croatia, was performed for patient records from January 2010 until June 2016. The search terms were "knee", "arthroscopy", and "ganglion cyst”, which yielded 12 consecutive patients. Clinical, radiological and histologic records of these patients were retrospectively reviewed by an independent examiner who was not involved in their treatment process.

The operative procedure was performed by the senior author (I.B.) in all patients. The procedure was conducted with the patient under spinal anesthesia, placed supine with the affected knee placed in the leg holder. A tourniquet was applied to the affected limb throughout the operation in all cases. Knee arthroscopy was performed using a 4.0-mm arthroscope angled at $30^{\circ}$. Standard anteromedial and anterolateral portals were used for arthroscopic access with the knee joint distended to $50 \mathrm{~mm} \mathrm{Hg}$ and using an arthroscopic infusion pump (Arthrex AR-6475 Continuous Wave IIIC, Arthrex Inc., Naples, FL, USA) throughout the procedure. Because of the localization of cysts in the posterior part of the knee in some patients, additional posteromedial, posterolateral and posterior trans-septal arthroscopic portals were required. The posteromedial and posterolateral portals were created according to the technique reported by Schreiber ${ }^{14}$ (Fig. 1). To visualize and manage the complete posterior compartment of the knee joint, a posterior trans-

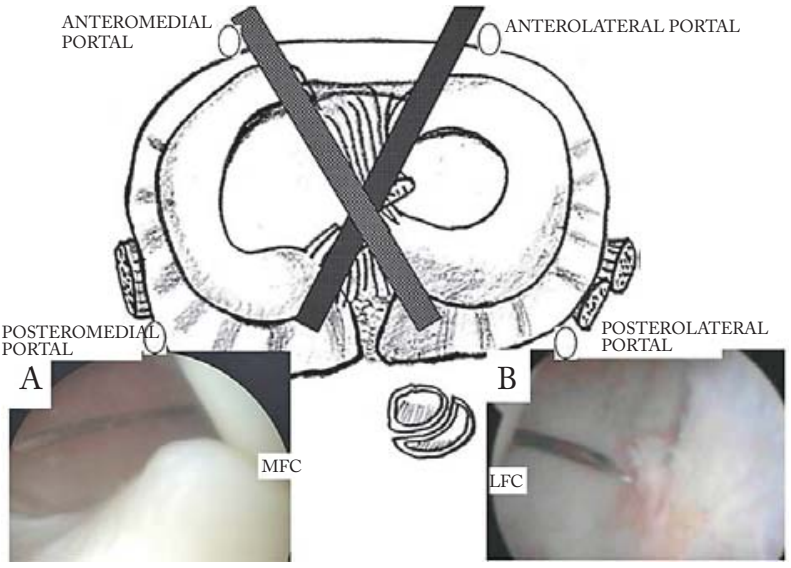

Fig. 1. Arthroscopic view of the posteromedial (A) and posterolateral (B) compartments through the intercondylar notch from the anterolateral and anteromedial portals. A needle is inserted just posteriorly to the medial (A) and lateral (B) femoral condyle at $5 \mathrm{~mm}$ above the tibial articular surface. $M F C$ : medial femoral condyle; LFC: lateral femoral condyle.

septal portal was established, as described by Ahn et $a l .^{15}$. The first step involved establishing a posteromedial portal, followed by posterolateral portal. An aperture through the posterior septum was created by a switching stick placed through the posterolateral portal while maintaining a view of the medial side of the septum using the arthroscope introduced through the posteromedial portal (Fig. 2). Once the trans-septal portal had been created, the arthroscope and instruments were easily interchanged through the two posterior portals using the posterior 'back and forth' approach described by Louisia et al. ${ }^{16}$. In one patient after standard arthroscopic exploration of the knee joint through the anterolateral and anteromedial portals, an open en-bloc excision was performed because of the large ganglion cystic formation arising from the infrapatellar fat pad.

Localization of the ganglion cysts was determined during arthroscopy followed by palpation of the cysts with a probe. All of them were smooth and elastic on probing. Then, cysts were punctured with an intramuscular needle and a jelly-like viscous fluid leaked from the cysts in all patients (Fig. 3). If appropriate, punch forceps were used to obtain a specimen for histologic examination before the entire cyst was excised with a shaver and/or radiofrequency ablation probe. Any other intra-articular pathology found during arthros- 

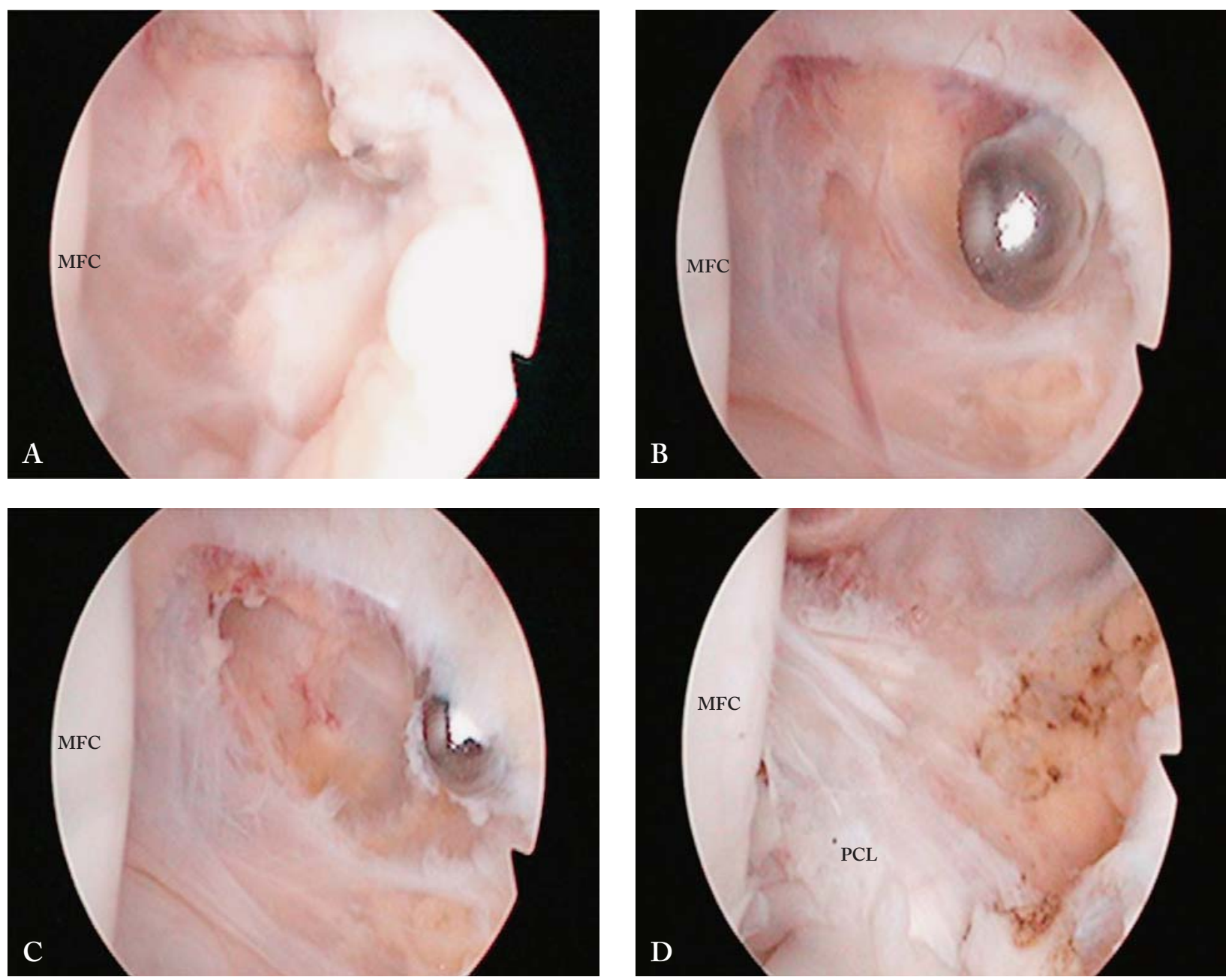

Fig. 2. Case 12, a 17-year-old female patient: (A) arthroscopic view from the posteromedial portal showing the making of an aperture in the posterior septum by a blunt trocar placed through the posterolateral portal; (B) arthroscopic view from the posteromedial portal showing a shaver in an aperture in the posterior septum. The shaver is placed into the knee through the posterolateral portal; (C) arthroscopic view from the posteromedial portal showing a cyst (arrow) above the posterior cruciate ligament. The shaver is placed into the knee through the posterolateral portal; (D) arthroscopic view from the posteromedial portal after arthroscopic debridement, which means complete resection of the cysts and cyst walls. MFC: medial femoral condyle, PCL: posterior cruciate ligament.

copy was also treated at the time. The postoperative rehabilitation program included early active motion and partial weight bearing with crutches for the first 3 weeks, followed by full weight bearing.

\section{Results}

Twelve patients (seven females and five males) were treated for intra-articular ganglion cyst of the knee joint (Table 1). The mean patient age was 26.4 (range, 16-46) years. Duration of the symptoms prior to the operation varied from 2 months to 3 years (mean, 17.1 months). All patients had preoperative MRI done which clearly visualized the cyst, and radiological interpretation of ganglion cysts in all cases. Only the patient with a partial ACL rupture had a history of prior minor knee trauma, whereas the remaining eleven patients developed knee pain without any history of trauma. Pain was the most common clinical presentation. In ten of the twelve patients, there was either minor or no additional pathology found in the knee besides the ganglion cyst. A single patient with 

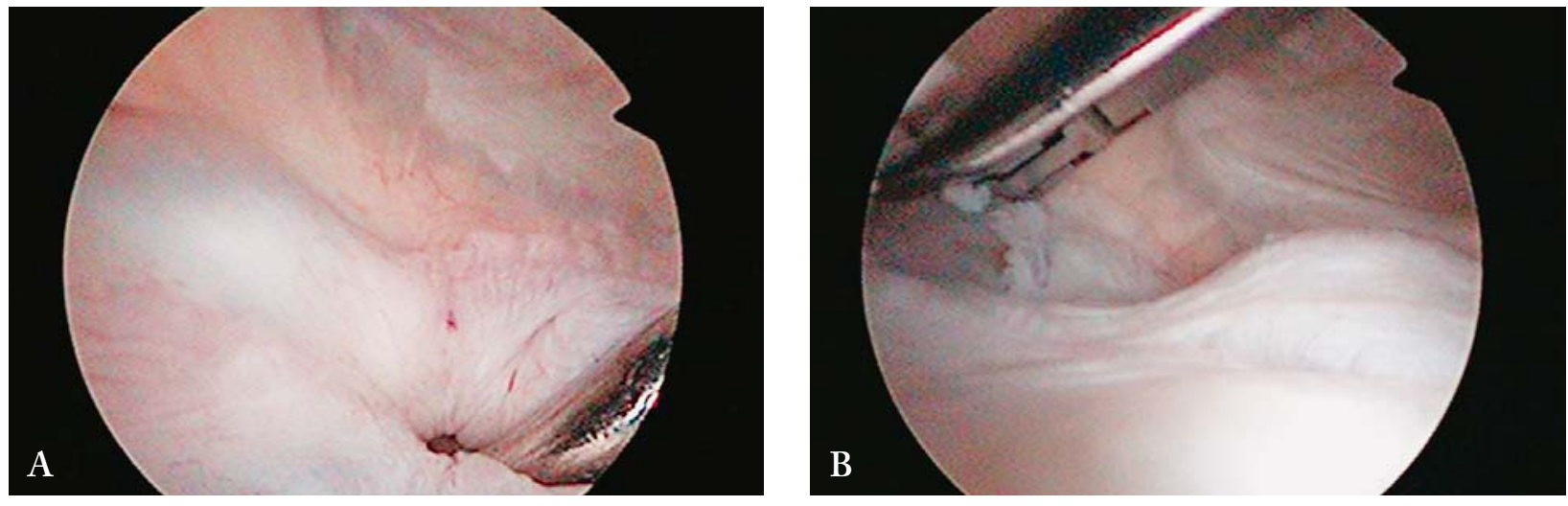

Fig. 3. Case 8, a 35-year-old male patient:

(A) arthroscopic view from the anterolateral portal showing a cyst (arrow) posteriorly to the posterior horn of the medial meniscus; (B) arthroscopic view from the anterolateral portal during resection of the tissue around the cyst. The instrument is placed into the knee through the posteromedial portal; (C) arthroscopic view from the anterolateral portal revealing yellow gelatinous content extruding from the cyst after being punctured with the instrument. The instrument is placed into the knee through the posteromedial portal.

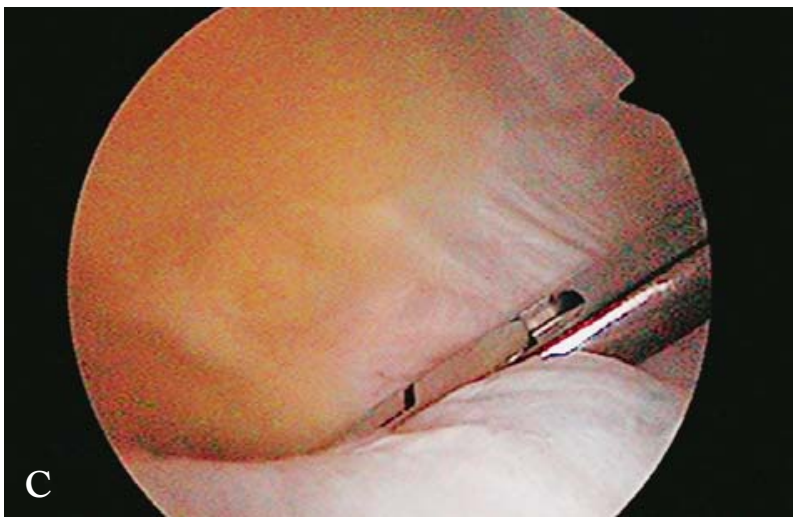

the cyst located in the anterior horn of the lateral meniscus had a small tear in the anterior horn of lateral meniscus, and the other with the cyst located between the ACL and PCL had a partial ACL rupture. No complications developed during surgery, and the postoperative period was uneventful in all patients. In nine patients where a sample could be obtained, findings of the histopathologic analysis of tissue from the cysts were consistent with ganglion cyst. The mean follow up was 43.5 (range, 9-83) months. No recurrence was recorded on the scheduled clinical follow up visits. All the patients remained symptom-free with full range of motion at follow up visits and there was no need for postoperative MRI in any of the patients. Also, all the patients were able to participate in recreational sports activities at the desired level after the surgery, and none of the patients returned to the operating room for any condition related to the operated knee.

\section{Discussion}

Symptomatic intra-articular ganglion cysts of the knee are successfully treatable with arthroscopy ${ }^{7-13}$.

Those that have larger diameter and are originating from extra-articular tissues may require an additional open approach after arthroscopic exploration of the knee $^{17-22}$.

Krudwig et al. ${ }^{9}$ report that intra-articular ganglion cysts of the knee were found in 85 of 8000 patients arthroscopically examined over a 15 -year period. Of these 85 cases, nine were symptomatic and 76 were incidental and asymptomatic findings on arthroscopy performed for treatment of osteoarthritic symptoms. There remains much controversy in the literature concerning the pathogenesis of ganglion cysts ${ }^{10-13}$. Several theories have been proposed, including displacement of synovial tissue during embryogenesis, proliferation of pluripotential mesenchymal cells, mucinous degeneration of connective tissue after trauma, and migration of synovial fluid into the surrounding tissues (synovial herniation theory $)^{10-13}$. It could also represent a congenital abnormality ${ }^{10-13}$. Histologic examination reveals that these fluid filled structures have no epithelial lining, confirming that they are not true cysts and therefore reject the theories of synovial herniation, favoring a degenerative cause. Despite many reports 
Table 1. Patient descriptive data

\begin{tabular}{|c|c|c|c|c|c|c|c|c|}
\hline No. & $\begin{array}{l}\text { Gender }{ }^{\ddagger} / \\
\text { age (yrs) }\end{array}$ & $\begin{array}{l}\text { Duration } \\
\text { of } \\
\text { symptoms } \\
\text { (months) }\end{array}$ & $\begin{array}{l}\text { Presenting } \\
\text { complaints }\end{array}$ & $\begin{array}{l}\text { Location } \\
\text { of ganglion }\end{array}$ & $\begin{array}{l}\text { Associated } \\
\text { pathology }\end{array}$ & $\begin{array}{l}\text { Arthroscopic } \\
\text { portals* }\end{array}$ & Histology & $\begin{array}{l}\text { Follow } \\
\text { up } \\
\text { (months) }\end{array}$ \\
\hline 1 & F/16 & 36 & $\begin{array}{l}\text { Pain on flexion, } \\
\text { loss of extension } \\
\text { and flexion } \\
\left(\mathrm{Ex} / \mathrm{Fx}^{ \pm} 0 / 10 / 90\right)\end{array}$ & $\begin{array}{l}\text { Between } \\
\text { ACL } \\
\text { and PCL }\end{array}$ & None & AL, AM, PL & Yes & 83 \\
\hline 2 & $\mathrm{~F} / 37$ & 12 & $\begin{array}{l}\text { Pain on flexion after } \\
\text { activities, especially } \\
\text { after running } \\
\text { or squatting }\end{array}$ & $\begin{array}{l}\text { Between } \\
\text { ACL } \\
\text { and PCL }\end{array}$ & None & $\begin{array}{l}\text { AL, AM, } \\
\text { PM }\end{array}$ & Yes & 72 \\
\hline 3 & $\mathrm{M} / 15$ & 12 & $\begin{array}{l}\text { Pain with loss } \\
\text { of extension of } 10^{\circ}\end{array}$ & $\begin{array}{l}\text { Anterior } \\
\text { ACL, distal } \\
\text { third }\end{array}$ & None & AL, AM & Yes & 60 \\
\hline 4 & $\mathrm{M} / 28$ & 5 & Pain on extension & $\begin{array}{l}\text { Anterior } \\
\text { ACL, } \\
\text { distal third }\end{array}$ & None & AL, AM & Yes & 54 \\
\hline 5 & $\mathrm{~F} / 26$ & 2 & $\begin{array}{l}\text { Pain, especially } \\
\text { on extreme flexion } \\
\text { or extension }\end{array}$ & $\begin{array}{l}\text { Between } \\
\text { ACL } \\
\text { and PCL } \\
\end{array}$ & $\begin{array}{l}\text { Partial } \\
\text { ACL } \\
\text { rupture }\end{array}$ & $\mathrm{AL}, \mathrm{AM}$ & Yes & 52 \\
\hline 6 & F/16 & 24 & $\begin{array}{l}\text { Pain and swelling at } \\
\text { anterolateral aspect of } \\
\text { the knee } 1 \mathrm{~cm} \text { above } \\
\text { the lateral joint line }\end{array}$ & $\begin{array}{l}\text { Anterior } \\
\text { horn lateral } \\
\text { meniscus }\end{array}$ & None & AL, AM & Yes & 49 \\
\hline 7 & $\mathrm{~F} / 28$ & 12 & $\begin{array}{l}\text { Pain on flexion, } \\
\text { loss of flexion } \\
\left(\mathrm{Ex} / \mathrm{Fx}^{ \pm} 0 / 0 / 90\right)\end{array}$ & $\begin{array}{l}\text { Posterior to } \\
\text { PCL }\end{array}$ & None & $\begin{array}{l}\text { AL, AM, } \\
\text { PM, PL, } \\
\text { trans-septal } \\
\end{array}$ & No & 44 \\
\hline 8 & $\mathrm{M} / 35$ & 12 & $\begin{array}{l}\text { Pain on flexion } \\
\text { after activities, } \\
\text { especially after } \\
\text { running or squatting }\end{array}$ & $\begin{array}{l}\text { Posterior } \\
\text { horn } \\
\text { medial } \\
\text { meniscus }\end{array}$ & None & $\begin{array}{l}\text { AL, AM, } \\
\text { PM }\end{array}$ & Yes & 38 \\
\hline 9 & $\mathrm{~F} / 46$ & 36 & $\begin{array}{l}\text { Pain on flexion, } \\
\text { loss of flexion } \\
\left(\mathrm{Ex} / \mathrm{Fx}^{ \pm} 0 / 0 / 90\right)\end{array}$ & $\begin{array}{l}\text { Posterior } \\
\text { to PCL }\end{array}$ & None & $\begin{array}{l}\text { AL, AM, } \\
\text { PM, PL, } \\
\text { trans-septal }\end{array}$ & No & 26 \\
\hline 10 & $\mathrm{M} / 15^{* *}$ & 36 & $\begin{array}{l}\text { Pain and visible mass } \\
\text { on lateral side of the } \\
\text { patellar tendon }\end{array}$ & $\begin{array}{l}\text { Infrapatellar } \\
\text { fat pad }\end{array}$ & None & AL, AM & Yes & 23 \\
\hline 11 & $\mathrm{M} / 38$ & 6 & $\begin{array}{l}\text { Pain and swelling } \\
\text { at anterolateral } \\
\text { aspect of the knee } \\
1 \mathrm{~cm} \text { above the } \\
\text { lateral joint line }\end{array}$ & $\begin{array}{l}\text { Anterior } \\
\text { horn lateral } \\
\text { meniscus }\end{array}$ & $\begin{array}{l}\text { Rupture of } \\
\text { anterior } \\
\text { horn } \\
\text { of lateral } \\
\text { meniscus }\end{array}$ & AL, AM & Yes & 12 \\
\hline 12 & $\mathrm{~F} / 17$ & 12 & $\begin{array}{l}\text { Pain on flexion } \\
\text { after activities, } \\
\text { clicking sensation } \\
\text { at } 90^{\circ} \text { of knee flexion }\end{array}$ & $\begin{array}{l}\text { Posterior to } \\
\text { PCL }\end{array}$ & None & $\begin{array}{l}\text { AL, AM, } \\
\text { PM, PL, } \\
\text { trans-septal }\end{array}$ & No & 9 \\
\hline
\end{tabular}

${ }^{\ddagger} \mathrm{F}=$ female $; \mathrm{M}=$ male; ${ }^{ \pm} \mathrm{Ex} / \mathrm{Fx}=$ extension/flexion; ${ }^{\mathrm{ACL}}=$ anterior cruciate ligament; $\mathrm{PCL}=$ posterior cruciate ligament; ${ }^{*} \mathrm{AL}=$ anterolateral portal; $\mathrm{AM}=$ anteromedial portal; $\mathrm{PL}=$ posterolateral portal; $\mathrm{PM}=$ posteromedial portal; trans-septal = trans-septal portal; $*$ * finished with open excision 

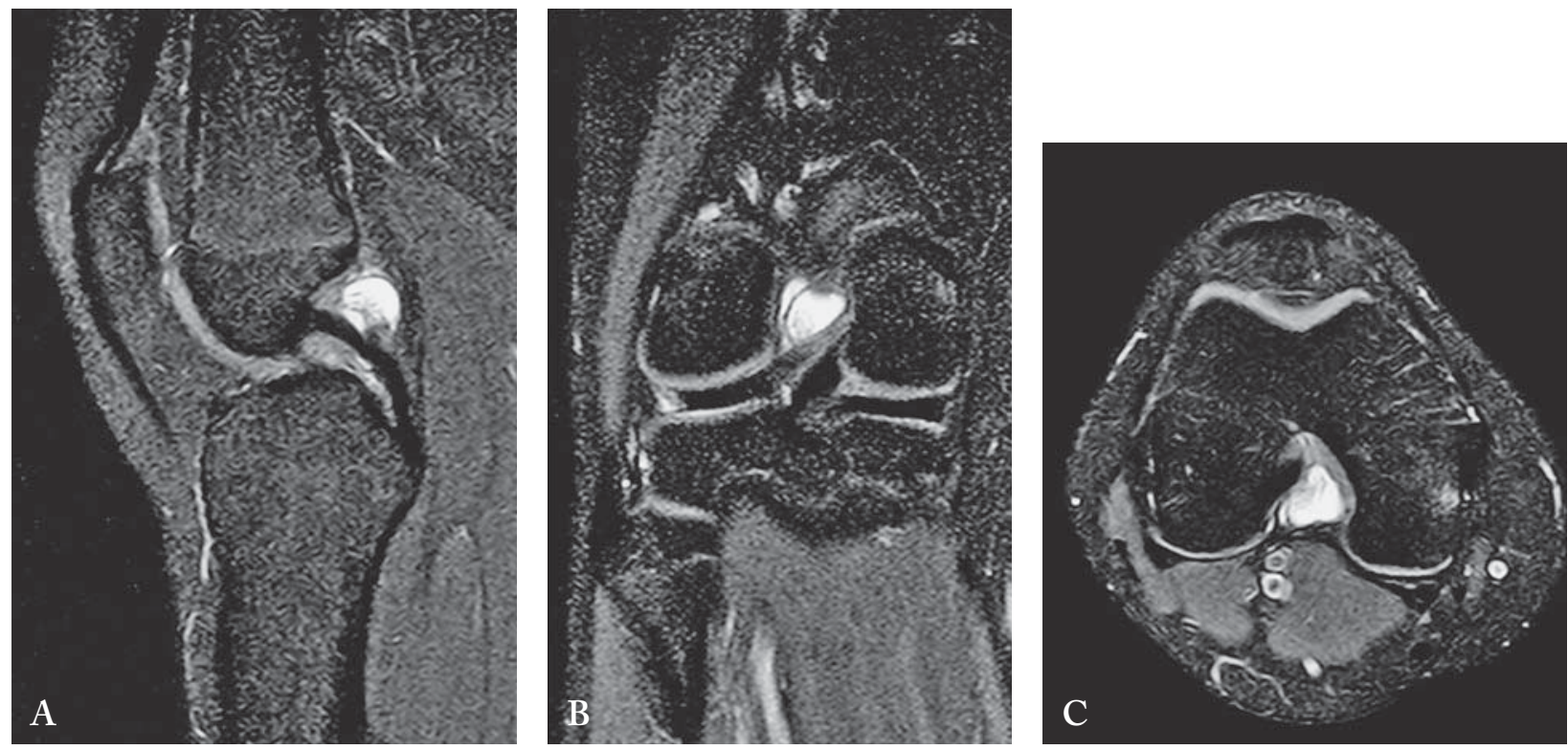

Fig. 4. Case 12, a 17-year-old female patient: (A) sagittal, (B) coronal, and (C) axial PDW MRI of the knee joint showing a well-defined, oval, hyperintense lesion located adjacently to the dorsal surface of the posterior cruciate ligament (PCL), consistent with a PCL ganglion cyst.

have emphasized that trauma is required for development of a ganglion cyst, it is postulated that repetitive microtrauma from joint and soft tissue motion may play an important role, which would be in accordance with our patients of which only one had a history of knee injury ${ }^{10-13}$.

Diagnosis of an intra-articular ganglion cyst of the knee requires radiographic work-up and cannot be based solely on the history and physical examination due to the variable presentation of symptoms. Knee pain, incomplete extension or flexion of the knee, pain at the extremes of motion, stiffness, and clicks are all commonly encountered symptoms ${ }^{3-13}$. Occasional findings include a palpable mass and erosion of bone $\mathrm{e}^{3-13}$. Primary imaging should be plain film radiographs of the symptomatic joint to rule out bony abnormalities or deformity of the joint. Secondary imaging of the knee should be an MRI. MRI has been recommended as the most sensitive, specific, accurate, and noninvasive method of detecting cystic lesions of the knees because of its multi-planar capability, superior identification of the anatomic and morphological inter-relation of the synovial tissues relative to the surrounding structures such as bone and vessels, and detection of additional joint diseases ${ }^{3-6}$. In our study, intra-articular ganglion cysts of the knee were clearly indicated in all patients by preoperative MRI imaging that exhibited homogeneous low-signal intensity on T1-weighted images and high-signal intensity on T2-weighted images (Fig. 4). Other imaging modalities such as CT and ultrasound are not recommended due to their low diagnostic value ${ }^{3-6}$.

Once the presence of a symptomatic intra-articular ganglion cyst has been identified, various treatment options including open or arthroscopic resection, ultrasound guided aspiration and CT guided aspiration have been described. Currently, arthroscopic debridement of ganglion cyst, which means complete resection of the cysts and cyst walls, is the most common method of treatment for symptomatic cysts (Fig. 5) 7-13 $^{7}$. Open surgery is necessary in particular cases only ${ }^{17-22}$. It has been reported that the possibility of incomplete removal of a huge cyst exists with arthroscopic surgery when the cyst diameter is more than $4.5 \mathrm{~cm}^{17}$. It is our opinion that open surgical excision should be reserved after arthroscopic exploration of the knee joint for large ganglion cysts arising from the infrapatellar fat pad. Image-guided percutaneous aspiration has been advocated as a cost-effective treatment that avoids the potential complications associated with surgical intervention; however, limited data exist regarding the use of this modality. DeFriend et al. ${ }^{23}$ report on two pa- 

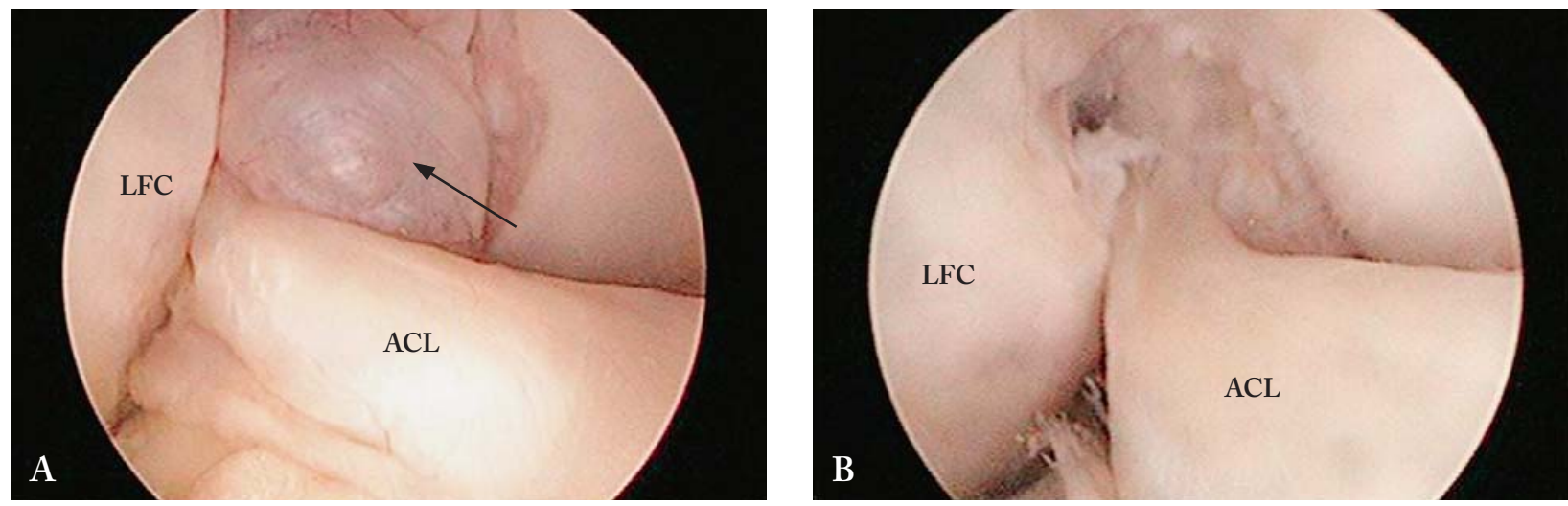

Fig. 5. Case 2, a 37-year-old female patient: (A) arthroscopic view from the anterolateral portal showing a cyst (arrow) between the anterior and posterior cruciate ligament; (B) arthroscopic view from the anterolateral portal after arthroscopic debridement, which means complete resection of the cysts and cyst walls. LFC: lateral femoral condyle, $A C L$ : anterior cruciate ligament.

tients with ganglion cysts of the PCL treated with ultrasound-guided aspiration. Both were symptom-free and without recurrence at the mean 1.5-year follow up. Nokes et al. ${ }^{24}$ report on two cases of ganglion cysts of the PCL of the knee treated with CT-guided aspiration and both patients had relief from pain and had no recurrence of the cysts at the 2-year follow up. Antonacci $e t a l .{ }^{25}$ have presented a series of three patients with ganglion cysts of the ACL treated with CTguided aspiration. At 1-year follow up, two patients were symptom-free without recurrence and one patient had recurrence within 3 months. Sonnery-Cottet et $a .^{26}$ describe an international professional soccer player with ACL ganglion cyst who was treated with CT-guided aspiration and who was asymptomatic at 2-year follow up during all sports and daily activities. However, the 2-year follow up MRI showed the continued presence of the ganglion cyst but with a significant reduction in its size. As cyst walls are not removed and recurrence of ganglion cysts may occur, we do not recommend ultrasound- or CT-guided percutaneous aspiration alone.

Unlike the ankle joint ${ }^{27}$, where ganglion cysts can recur after surgery, recurrence has not yet been a problem following arthroscopic or open surgical treatment for intra-articular ganglion cysts of the knee ${ }^{7-13}$. Brown and Dandy ${ }^{7}$ report that $95 \%$ of patients they treated with arthroscopic total resection had no recurrence. Complete resection of the ganglion cyst is considered to be essential in treating this disorder. This means complete removal of the cysts and cyst walls. Precise location of the intra-articular ganglion cyst is important in planning the arthroscopic approach. We found that the most significant task in arthroscopic procedure was establishing proper visualization of the entire cyst. It is our opinion that such an aim can only be attained through comprehensive procedure planning based on MRI studies and confident use of posterior as well as anterior portals, which requires the skill of an experienced arthroscopist and excellent knowledge of regional anatomy in order to avoid complications. Lubowitz et al. ${ }^{28}$ performed 100 consecutive knee arthroscopies with transcondylar notch views and found that posterolateral visualization was achieved in 100\% of the procedures (and in 93\% during the first attempt) with a $4 \%$ rate of mild iatrogenic cartilage damage. Posteromedial visualization was achieved in $97 \%$ of the procedures ( $82 \%$ during the first attempt) with a $28 \%$ rate of mild iatrogenic cartilage damage and 3\% rates of moderate and severe damage. Only two clinical studies have reported on neurovascular complications directly related to posteromedial portal creation. Gold et al. ${ }^{29}$ report on one saphenous nerve injury among 78 posteromedial portals placed, whereas Ogilvie-Harris et al..$^{30}$ report on three saphenous nerve injuries and two saphenous vein injuries after establishment of 179 posteromedial portals. Complications are rarely associated with the creation of a posterolateral accessory portal, but there are some reports of injuries of the common peroneal nerve during the placement of posterolateral portals, mostly because of incorrect placement of the portal ${ }^{31}$. 
The posterior compartment of the knee was a socalled 'blind spot' for arthroscopists until the creation of a posterior trans-septal portal, as described by Ahn et al. ${ }^{15}$ and Louisia et al. ${ }^{16}$. This portal allows passage of the arthroscope or instruments between the posteromedial and posterolateral compartments and provides a large working space and broader field of view for better instrument maneuverability in the posterior aspect of the knee. Various applications of the posterior transseptal portal have been proposed including total arthroscopic synovectomy of the posterior compartment, removal of loose bodies or tumors behind the PCL, suture fixation of an avulsion of the PCL from the tibia, reconstruction of the PCL, and repair of the posterior horn or root of the medial meniscus. The popliteal artery, the most anterior structure of the popliteal neurovascular bundle, is clearly at risk during establishment of the trans-septal portal ${ }^{15,16,32-35}$. To date, no cases of popliteal artery injury during creation of the trans-septal portal have been reported, to our knowledge. Ohishi et al. ${ }^{32}$ report that they performed arthroscopic surgeries via trans-septal portal in the posterior compartments of 161 knees and encountered no nerve or vascular injury. In their study, postoperative complications were encountered only in four $(2.5 \%)$ knees, including superficial infection of the posteromedial portal in two knees, subcutaneous hematoma in one knee, and deep infection of the posterolateral portal in one knee.

This study had several limitations inherent to retrospective case series design, including the lack of control group and a relatively small number of cases, as well as the lack of histologic confirmation of ganglion cyst in all patients.

Intra-articular ganglion cysts of the knee, although rare, should be included in the list of differential diagnoses when the patient complains of pain or swelling or mechanical symptoms of the knee. When a symptomatic patient is diagnosed with a ganglion cyst of any location, it seems to be advisable to remove it arthroscopically regardless of other possible findings in the knee. To achieve this goal, appropriate visualization is indispensable. It is our opinion that such an aim can only be attained through comprehensive procedure planning, based on MRI studies and confident use of posterior, as well as anterior portals during knee arthroscopy. In concordance with other reports, we would like to point out that an intra-articular ganglion cyst of the knee can be successfully treated by arthroscopic debridement, which means complete resection of the cyst and cyst walls. It is our opinion that open surgical excision should be reserved solely for large cysts arising from the infrapatellar fat pad after arthroscopic exploration of the knee.

\section{References}

1. Stein D, Cantlon M, Mackay B, Hoelscher C. Cysts about the knee: evaluation and management. J Am Acad Orthop Surg. 2013;21:469-79. doi: 10.5435/JAAOS-21-08-469

2. Caan P. Zystenbildung (Ganglion) im Ligamentum cruciatum ant. genus. Dtsch Z Chir. 1924;186:403-8. (in German)

3. Bui-Mansfield LT, Youngberg RA. Intraarticular ganglia of the knee: prevalence, presentation, etiology, and management. AJR Am J Roentgenol. 1997;168:123-7.

4. Kim MG, Kim BH, Choi JA, et al. Intra-articular ganglion cysts of the knee: clinical and MR imaging features. Eur Radiol. 2001;11:834-40. doi: 10.1007/s003300000713

5. Huang GS, Lee CH, Chan WP, et al. Ganglion cysts of the cruciate ligaments. Acta Radiol. 2002;43:419-24.

6. Mao Y, Dong Q, Wang Y. Ganglion cysts of the cruciate ligaments: a series of 31 cases and review of the literature. BMC Musculoskelet Disord. 2012;13:137. doi: 10.1186/1471-247413-137

7. Brown MF, Dandy DJ. Intra-articular ganglia in the knee. Arthroscopy. 1990;6:322-3.

8. Kang CN, Kim DW, Kim DJ, Kim SJ. Intra-articular ganglion cysts of the knee. Arthroscopy. 1999;15:373-8.

9. Krudwig WK, Schulte KK, Heinemann C. Intra-articular ganglion cysts of the knee joint: a report of 85 cases and review of the literature. Knee Surg Sports Traumatol Arthrosc. 2004;12:123-9. doi: 10.1007/s00167-003-0372-9

10. Zantop T, Rusch A, Hassenpflug J, Petersen W. Intra-articular ganglion cysts of the cruciate ligaments: case report and review of the literature. Arch Orthop Trauma Surg. 2003;123:195-8. doi: 10.1007/s00402-003-0494-Z

11. Sarimo J, Rantanen J, Helttula I, Orava S. Intra-articular cysts and ganglia of the knee: a report of nine patients. Knee Surg Sports Traumatol Arthrosc. 2005;13:44-7. doi: 10.1007/s001 67004-0519-3

12. Parish EN, Dixon P, Cross MJ. Ganglion cysts of the anterior cruciate ligament: a series of 15 cases. Arthroscopy. 2005;21: 445-7. doi: 10.1016/j.arthro.2004.12.008

13. Lunhao B, Yu S, Jiashi W. Diagnosis and treatment of ganglion cysts of the cruciate ligaments. Arch Orthop Trauma Surg. 2011;131:1053-7. doi: 10.1007/s00402-011-1286-5

14. Schreiber SN. Arthroscopy update \#9. Posterior compartment observation and instrumentation in the knee using anterome- 
dial and anterolateral portals and an interchangeable cannula system. Orthop Rev. 1991;20:67-8, 73, 76-80.

15. Ahn JH, Ha CW. Posterior trans-septal portal for arthroscopic surgery of the knee joint. Arthroscopy. 2000;16:774-9. doi: 10.1053/jars.2000.7681

16. Louisia S, Charrois O, Beaufils P. Posterior "back and forth" approach in arthroscopic surgery on the posterior knee compartments. Arthroscopy. 2003;19:321-5. doi: 10.1053/jars. 2003.50082

17. David KS, Korula RJ. Intra-articular ganglion cyst of the knee. Knee Surg Sports Traumatol Arthrosc. 2004;12:335-7. doi: 10.1007/s00167-003-0476-2

18. Yilmaz E, Karakurt L, Ozercan I, Ozdemir H. A ganglion cyst that developed from the infrapatellar fat pad of the knee. Arthroscopy. 2004;20:e65-8. doi: 10.1016/j.arthro.2004.06.023

19. Liu PC, Chen CH, Huang HT, et al. Snapping knee symptoms caused by an intra-articular ganglion cyst. Knee. 2007;14: 167-8. doi: 10.1016/j.knee.2006.12.003

20. Amin M, Torreggiani W, Sparkes J. Infrapatellar ganglion that developed from infrapatellar fat and had minimal intraarticular extension. Knee Surg Sports Traumatol Arthrosc. 2008;16: 179-81. doi: 10.1007/s00167-007-0406-9

21. Nikolopoulos I, Krinas G, Kipriadis D, Ilias A, Giannakopoulos A, Kalos S. Large infrapatellar ganglionic cyst of the knee fat pad: a case report and review of the literature. J Med Case Rep. 2011;5:351. doi: 10.1186/1752-1947-5-351

22. Saha P, Bandyopadhyay U, Mukhopadhyay AS, Kundu S, Mandal S. Ganglion cyst of knee from Hoffa's fat pad protruding anterolaterally through retinacular rent: a case report. J Orthop Case Rep. 2015;5:69-71. doi: 10.13107/jocr.22500685.313

23. DeFriend DE, Schranz PJ, Silver DA. Ultrasound-guided aspiration of posterior cruciate ligament ganglion cysts. Skeletal Radiol. 2001;30:411-4.

24. Antonacci VP, Foster T, Fenlon H, Harper K, Eustace S. Technical report: CT-guided aspiration of anterior cruciate ligament ganglion cysts. Clin Radiol. 1998;53:771-3.

25. Nokes SR, Koonce TW, Montanez J. Ganglion cysts of the cruciate ligaments of the knee: recognition on MR images and CT guided aspiration. AJR Am J Roentgenol. 1994; 162:1503.

26. Sonnery-Cottet B, Guimarães TM, Daggett M, et al. Anterior cruciate ligament ganglion cyst treated under computed tomography-guided aspiration in a professional soccer player. Orthop J Sports Med. 2016;4:2325967116644585. doi: 10.1177/2325967116644585

27. Ferkel RD, Field J, Scherer WP, Bernstein ML, Kasimian D. Intraosseous ganglion cysts of the ankle: a report of three cases with long-term follow-up. Foot Ankle Int. 1999;20:384-8.

28. Lubowitz JH, Rossi MJ, Baker BS, Guttmann D. Arthroscopic visualization of the posterior compartments of the knee. Arthroscopy. 2004;20:675-80. doi: 10.1016/S07498063(04) 00547-X

29. Gold DL, Schaner PJ, Sapega AA. The posteromedial portal in knee arthroscopy: an analysis of diagnostic and surgical utility. Arthroscopy. 1995;11:139-45.

30. Ogilvie-Harris DJ, Biggs DJ, Mackay M, Weisleder L. Posterior portals for arthroscopic surgery of the knee. Arthroscopy. 1994;10:608-13.

31. Kramer DE, Bahk MS, Cascio BM, Cosgarea AJ. Posterior knee arthroscopy: anatomy, technique, application.J Bone Joint Surg Am. 2006;88 Suppl 4:110-21. doi: 10.2106/JBJS.F.00607

32. Ohishi T, Takahashi M, Suzuki D, Matsuyama Y. Arthroscopic approach to the posterior compartment of the knee using a posterior transseptal portal. World J Orthop. 2015;6:505-12. doi: 10.5312/wjo.v6.i7.505

33. Kim JH, Shin DE, Dan JM, Nam KS, Ahn TK, Lee DH. Arthroscopic suture anchor repair of posterior root attachment injury in medial meniscus: technical note. Arch Orthop Trauma Surg. 2009;129:1085-8. doi : 10.1007/s00402-008-0810-8

34. Yoo JH, Kim EH, Min KD, Lee BI. Arthroscopic excision of the ganglion in the posterior septum by posterior trans-septal portal: report of two cases. Arch Orthop Trauma Surg. 2009;129:1047-51. doi: 10.1007/s00402-008-0703-x

35. Tsai TY, Yang YS, Tseng FJ, et al. Arthroscopic excision of ganglion cysts of the posterior cruciate ligaments using posterior trans-septal portal. Arthroscopy. 2012;28:95-9. doi: 10.1016/j.arthro.2011.07.013 
Sažetak

\section{GANGLIJSKE CISTE KOLJENA - RETROSPEKTIVNI PRIKAZ NIZA UZASTOPNIH SLUČAJEVA}

\section{Bojanić, D. Dimnjaković i T. Smoljanović}

Cilj ovoga istraživanja bio je prikazati rezultate kirurškog liječenja simptomatskih ganglijskih cista smještenih unutar koljena. U razdoblju od siječnja 2010. do lipnja 2016. godine 12 je bolesnika (7 žena i 5 muškaraca) operirano u Klinici za ortopediju KBC-a Zagreb i Medicinskog fakulteta Sveučilišta u Zagrebu. Srednja životna dob u trenutku kirurškog zahvata bila je 26,4 (raspon, 16-46) godine. Srednje trajanje simptoma prije zahvata bilo je 17,1 (raspon, 2-36) mjeseci. Bol je bila vodeći simptom u bolesnika, a prije zahvata u svih je bolesnika načinjena i magnetska rezonanca koljena koja je uz dijagnostičko značenje pomogla i u planiranju artroskopskog zahvata. Kod svih je bolesnika nakon detaljnog artroskopskog pregleda koljena standardnim artroskopskim pristupima locirana ganglijska cista te je nakon uzimanja komadića tkiva za patohistološku analizu u 11 bolesnika u potpunosti resecirana uz pomoć motoriziranog instrumenta, dok je u jednog bolesnika zbog lokalizacije i veličine ciste bilo potrebno načiniti otvorenu eksciziju. Svi su kirurški zahvati, kao i rano poslijeoperacijsko razdoblje, protekli bez komplikacija. Srednje vrijeme praćenja bolesnika bilo je 43,5 (raspon, 9-83) mjeseci, a u tom se razdoblju nije pojavio recidiv niti kod jednog bolesnika. Na posljednjem kontrolnom pregledu svi su bolesnici bili bez simptoma uz pun opseg kretnja operiranog koljena. Ovo je istraživanje pokazalo da se, usprkos različitim prezentacijama simptomatskih intraartikularnih ganglijskih cista koljena, kirurškim liječenjem postižu odlični rezultati i potpun funkcionalni oporavak koljena u bolesnika.

Ključne riječi: Ganglijske ciste - dijagnostika; Ganglijske ciste - terapija; Koljeno - dijagnostičko snimanje; Koljeno - kirurgija; Artroskopija; Hrvatska 